Journal of Research in Interprofessional

Practice and

Education

Vol. 10.1

2020

\footnotetext{
a. Department of Health, Bjørknes University

College, Oslo, Norway

b. Department of Nursing and Health Promotion,

Faculty of Health Sciences, Oslo Metropolitan University, Oslo, Norway

c. Department of

Physiotherapy, Faculty

of Health Sciences, 0slo

Metropolitan University, Oslo, Norway

d. Lovisenberg Diaconal

University College, Oslo,

Norway

* Equally contributing as

first authors
}

\title{
Nutrition Students' Experiences of Interprofessional Learning in a Nursing Home
}

\author{
Ella Heyerdahl ${ }^{\mathrm{a} *}$, RD, MS; Marte Ottesen ${ }^{\mathrm{a} *}, \mathrm{RD}, \mathrm{MS}$; \\ Marianne Molin ${ }^{\mathrm{ab}}$, PhD; Christine Hillestad Hestevikc, PhD; \\ Venke Marion Sørlie ${ }^{\mathrm{d}}$, Professor; Gerd Sylvi Sellevold ${ }^{\mathrm{d}}$, Docent
}

\begin{abstract}
Background: Interprofessional experience is vitally important for nutrition students, as nutritionists often find themselves working independently in a team with other professionals. Few studies have explored qualitatively how nutrition students perceive learning activities in an interprofessional setting.

Methods and Findings: Third-year bachelor's degree nutrition students participated in a focus group interview after interprofessional learning in a nursing home. A qualitative study with a phenomenological-hermeneutical approach was conducted to investigate lived experiences. One theme emerged from the data analysis: A professional understanding of oneself and others. Being acknowledged as a professional, being an active participant, and collaborating to enhance resident care were revealed as sub-themes.

Conclusions: A short period of interprofessional learning in an authentic setting may expand students' experiences and enhance professional confidence.

Keywords: Nutrition students; Lived experience; Interprofessional education; Nursing home; Phenomenological-hermeneutical method
\end{abstract}

Journal of Research in Interprofessional Practice and Education (JRIPE)

Vol. 10.1

(c) 2020

doi: $10.22230 /$ jripe.2020

v10n1a305

Corresponding author: Ella Heyerdahl. Email:

ella.heyerdahl@bhioslo.no

\section{Introduction}

Authentic, first-hand experience is of the utmost importance in preparing nutrition students for their future professional role [1,2,3]. Officially accredited higher-education programs in nutrition are quite new from a historical perspective, particularly when compared to established professions such as medicine, nursing, and dentistry $[4,5]$. Furthermore, nutrition programs have differed substantially both in scope and length across learning institutions and geographical borders $[1,5,6,7]$. In recent years, a lot of work has been done to establish international competency standards that require practical training in professional settings as an integral part of the academic curricula. These are generally stated, however, and are still in the process of being implemented in many places. Hence, students' learning approaches and activities 
2

Nutrition Students' Experiences of Interprofessional Learning

Heyerdahl, Ottesen, Molin, Hestevik, Sørlie, \& Sellevold

Journal of Research in Interprofessional Practice and Education

Vol. 10.1

2020 may not yet meet these standards, let alone ensure relevant practical training that allows nutrition students to develop and perfect their future professional skills.

As nutrition students often find themselves working quite independently upon graduation, training nutrition students to be professionally self-sufficient may seem expedient $[1,8,9]$. However, to reach nutritional goals effectively, professionals within this field also need to hold the skills required to master the role of a functional team member in order to increase the performance and output of interprofessional collaboration whenever feasible $[8,10]$. Setting the stage to ensure effective interprofessional collaboration has been a political priority for years in order to enable healthcare systems to cope with the challenges ahead $[11,12]$.

Interprofessional education (IPE) is a learning model in which both multidisciplinary theory and practice are fundamental elements. An important aspect of IPE is the idea that students from different professions are brought together to learn from each other and obtain positive attitudes toward other professions [13]. In IPE, gaining mutual respect and acknowledgement is considered to be a condition for fruitful interaction and for the development of good practice. The incorporation of IPE in nutrition and dietetic study programs is currently limited [14].

Nutrition students may find future employment in various positions and professional roles, such as in research, academia, sports, industry, public health, or as freelance consultants [8]. One area in which nutrition competence is needed is in preventing undernutrition among the aging population in nursing homes, where the prevalence of undernutrition is high $[15,16]$. Elderly people as a nutritional risk constitute a major public health concern that should be dealt with through multidisciplinary efforts involving evidence-based nutrition competence $[17,18,19]$. In this regard, health workers in possession of such competence hold a key position in health prevention teams addressing the well-being of the elderly $[10,20]$.

Studies investigating nutrition students' involvement in IPE have found improved role clarification [21,22,23], increased student confidence [24,25], positive attitudes toward interprofessional teamwork, and readiness for interprofessional teamwork $[26,27,28,29]$. Few studies have explored qualitatively how students perceive learning activities in an interprofessional setting [22]. Further, none of these studies specifically explore the aging population within the setting of nursing homes. Hence, the aim of this study was to explore nutrition students' lived experiences of interprofessional learning in a nursing home.

\section{Methods}

Design

This study was part of a larger participatory action research (PAR) project entitled, Multidisciplinary Learning to Ensure Quality in Nutritional Care in Nursing Homes. This qualitative study was conducted using a phenomenological-hermeneutical method.

\section{Setting and participants}

The student practice took place in the ward of a nursing home in a larger city in 
JRIPE

3

Nutrition Students' Experiences of Interprofessional Learning

Heyerdahl, Ottesen, Molin, Hestevik, Sørlie, \& Sellevold
Norway. At the time of the project, the ward had 40 long-term elderly residents with multiple comorbidities and frailties, including dementia. The ward had 31 permanent employees, including seven nurses, 14 auxiliary nurses, and ten assistant nurses. One hot meal per day was produced in a large external kitchen, delivered to the ward, and served to the residents by the healthcare providers (HCPs). The other meals were prepared on the wards.

Three undergraduate nutrition students participated in the project. The participants carried out nutritional risk screening on some of the residents in collaboration with nursing students and under the supervision of a nurse. The learning activities are outlined in Table 1. The students were taught how to develop a detailed individual nutrition plan (INP) for residents who were at nutritional risk and then completed the plan under the supervision of a registered dietitian. The INP included the patient's nutritional status, dietary intake, requirements, and individual nutritional treatment measures, including information about physical, psychological, and social factors that may influence nutrient intake.

Table 1: Phases of the nutrition students' learning activities

\begin{tabular}{|l|l|}
\hline \multicolumn{2}{|c|}{ LEARNING ACTIVITIES } \\
\hline PHASES & DESCRIPTION \\
\hline \multirow{4}{*}{ Preparation } & Getting information about the project and its purpose \\
\cline { 2 - 3 } & Getting information about the ward and the residents \\
\cline { 2 - 3 } & Getting acquainted with the rest of the team \\
\cline { 2 - 3 } & Sharing theoretical knowledge \\
\hline \multirow{5}{*}{ Screening } & Screening residents for undernutrition \\
\cline { 2 - 3 } & Assessing residents' nutritional status \\
\cline { 2 - 3 } & Completing a three-day dietary record of residents at risk \\
\hline \multirow{3}{*}{ and reflection } & Assessing residents' energy, macro-nutrient, micro-nutrient, and fluid intake \\
\hline & $\begin{array}{l}\text { Developing individual nutrition care plans in the two workshops/team-meetings with the } \\
\text { nursing students and healthcare providers, under the supervision of a registered dietitian }\end{array}$ \\
\cline { 2 - 3 } & $\begin{array}{l}\text { Sharing experiences, discussions, and reflections together with the nursing students, health- } \\
\text { care providers, and supervisors regarding the nutrition care plan and other recommendations } \\
\text { concerning the residents }\end{array}$ \\
\cline { 2 - 3 } & Re-evaluating the nutrition plans and other recommendations \\
\hline
\end{tabular}

The students had four planned meeting points with the nursing students, HCPs, and supervisors. Supervisors were college teachers from all participating programs. There was one introductory meeting held during the preparation phase, as well as two workshops, and one dialogue-based teaching session held during the implementation and reflection phase (Table 1). The students spent four days in total on the ward (one day spent screening and three days taking dietary records). The total duration of the learning activities was six weeks.
Journal of Research in Interprofessional Practice and Education

Vol. 10.1

2020 
Nutrition Students' Experiences of Interprofessional Learning

Heyerdahl, Ottesen, Molin, Hestevik, Sørlie, \& Sellevold

Journal of Research in Interprofessional Practice and Education

Vol. 10.1

2020
Journal of Research in Interprofessional Practice and Education

\section{Ethical considerations}

The Norwegian Centre for Research Data (NSD) approved this project. The participants were given written and oral information about the study, and informed written consent was obtained from the participants prior to participation. The participants could at any time withdraw from the study. They were guaranteed confidentiality and anonymity in the presentation of the narratives from the focus group interview. As in Ricoeurs's [30] method of interpretation, anonymity is ensured as the researchers relate to the data as one collective text.

\section{Data collection}

The students participated in a focus-group interview shortly after they had completed their learning activities [31]. The interview was led by an experienced facilitator, and two moderators were present. The moderators took notes and were invited to ask follow-up questions. The interview was audiotaped and transcribed verbatim. The duration of the interview was approximately 60 minutes.

Open-ended questions were asked to encourage the students to narrate as freely as possible. Mishler [32] argues that using open-ended questions is likely to make most informants tell a story or an event. The students were posed one open-ended question: "Can you describe your experiences participating in the project?" During the interview the students were asked follow-up questions such as, "Can you tell more about this," and clarifying questions such as, "You talk about different competencies. Could you give an example of this?"

\section{Data analyses}

A phenomenological-hermeneutical method for researching lived experience developed by Lindseth and Norberg [33] and inspired by Ricoeur [30] was chosen for analyzing the data. This method was designed to explore lived experiences and was considered appropriate for exploring the students' experiences participating in the multidisciplinary learning project. The data material was seen as one text, giving the researchers a higher degree of freedom to find its meaning [30,33]. The analytic process constitutes three methodological steps: 1) naïve reading, 2) thematic structural analysis, and 3) comprehensive understanding. In line with the phenomenological-hermeneutical method, the researchers moved back and forth between the whole text and parts of the text and between understanding and explanation.

\section{Naïve reading}

First, the researchers performed a naïve reading, independent of one another, in order to gain a sense of the whole. Experiences from the naïve reading were shared, reflected on, and discussed. The researchers noted the rich experiences the students had, despite their short period of practice on the ward. They were moved by the students' narratives describing their own professional role in relation to the residents, next of kin, HCPs, and other students. 
5

Nutrition Students' Experiences of Interprofessional Learning

Heyerdahl, Ottesen, Molin, Hestevik, Sørlie, \& Sellevold
Journal of Research in Interprofessional Practice and Education

Vol. 10.1

2020

\section{Structural analysis}

A structural analysis was conducted to explain the text's meaning. The structural analysis involved identifying and extracting meaning units from the whole text. This was initially done by the first authors. The units of meaning were then reflected on in the light of the naive understanding of all the co-authors through comments and oral discussions. The themes revealed by the structural analysis are presented in the "Results" section.

\section{Comprehensive understanding}

A critical interpretation aimed at gaining a comprehensive understanding of the text's meaning was done in the final stage of the analysis. The understanding of the text's meaning was based on the authors' pre-understanding, the naïve reading, and the results of the structural analysis. A critical analysis was made in light of relevant theories and previous research. It is explored in the "Discussion" section.

\section{Results}

Based on the structural analysis, one main theme and three sub-themes were revealed as presented in Table 2.

\section{Table 2: Theme and sub-themes revealed by the structural analyses}

\begin{tabular}{|l|l|}
\hline THEME & SUB-THEMES \\
\hline \multirow{3}{*}{$\begin{array}{l}\text { A professional understanding } \\
\text { of oneself and others }\end{array}$} & Being acknowledged as a professional \\
\cline { 2 - 2 } & Being an active participant \\
\cline { 2 - 2 } & Collaborating to enhance resident care \\
\hline
\end{tabular}

A professional understanding of oneself and others Being acknowledged as a professional

As a result of their practice on the ward, the students cultivated a better understanding of their own role in a workplace setting. They saw a need for their nutritional competences in the nursing home. They experienced that their presence contributed to an increased focus on nutritional care and to new nutritional measures being implemented throughout their practice period.

The students reported that the HCPs in the nursing home felt uncertain and lacked in-depth competence about nutrition, but that they were eager to learn more. The students reported that the HCPs asked questions and wanted nutritional advice from them. The HCPs also wanted to see the individual nutrition plans (INPs) that the nutrition and nursing students had developed to compare them with their own INPs. This recognition of their nutritional expertise made the students aware of their ability to make a difference to the ward's nutritional practice. As one student reported, 'There are often simple measures available that may improve the residents' 
6

Nutrition Students' Experiences of Interprofessional Learning

Heyerdahl, Ottesen, Molin, Hestevik, Sørlie, \& Sellevold

Journal of Research in Interprofessional Practice and Education

Vol. 10.1

2020 nutritional status, measures which the nurses and nursing students do not think of due to their different professional perspective."

The students also reported a lack of routines concerning nutritional practice on the ward. They described offering new ideas to complement existing expertise, hence widening their own horizons and those of the HCPs. According to the students, there was a lot of confusion and uncertainty within the area of nutrition among HCPs. They emphasized the need for a person with the right competence to answer questions concerning nutrition-related issues. They also reflected on how nutrition competence is needed in many areas in society, including some areas where it is not yet recognized as necessary.

The students described how their time on the ward enabled them to see themselves as future health workers. They gained an understanding of how they can contribute in different institutions and organizations, describing how the learning activities promoted this understanding. One student said, "I have experienced that the knowledge we possess is useful to others." The students also expressed that the practice on the ward increased their motivation and self-confidence, with one reporting, "It was encouraging to experience that we could add something new."

\section{Being an active participant}

The students reported an overall positive experience. They described being invited by the HCPs to observe and participate in the nutritional care practice. One student said, "It was a nice experience communicating practical knowledge to the HCPs and to see how they showed increased involvement as well as understanding on what is required to carry out different nutrition-related tasks." Being the only nutrition student on the ward was reported as an advantage, as it enforced more active participation. Students expressed that they felt that the payoff was great considering the short period they spent on the ward.

While in their active participant roles, the students were able to pinpoint a direct example. They discovered that the HCPs were unsure of the meaning of an "energyenriched meal." This prompted the students to contact the central kitchen personnel and arrange for them to gather the nutritional information for the meals labelled "enriched" and communicate this information to the HCPs. According to the students, the kitchen personnel and the HCPs appreciated receiving this feedback. This encouraged the students to suggest changes in the residents' routines to ensure they were provided with the customized food to which they are entitled.

The students discovered that the residents' nutritional care was not always evidence based, as the HCPs seemed to prepare food according to their own personal preferences rather than the residents' needs and preferences. They described how they communicated this to the HCPs. According to the students, some HCPs focused on a "healthy diet" for the residents instead of focusing on aspects more relevant in nutrition care for the elderly, such as enjoyable meals and energy enrichment. They expressed being met with resistance when they recommended using more sugar and butter. One student described how they responded to this by actively sharing their knowledge, "I said to the HCPs directly that it is better to pro- 
7

Nutrition Students' Experiences of Interprofessional Learning

Heyerdahl, Ottesen, Molin, Hestevik, Sørlie, \& Sellevold

Journal of Research in Interprofessional Practice and Education

Vol. 10.1

2020 vide extra energy and that they do not need to consider healthy choices for a woman of 93 with eating challenges."

\section{Collaborating to enhance resident care}

The interprofessional teamwork and the sharing of knowledge with the nursing students and other HCPs was described as valuable. One student described the experience by saying, "I acknowledge the value of interprofessional teamwork, of being able to learn from each other's differing knowledge and experience. The nurses have competence within many areas in which we are lacking and vice versa."

The nutrition students and the nursing students collaborated on developing INPs for the residents. Through this collaboration, they experienced how their different views on care issues could complement each other. For example, the nutrition students were interested in possible side-effects of medications that could influence appetite or other factors related to food intake or digestion, and the nursing students were more focused on medication dosage.

The nutrition students considered receiving feedback from the nursing students and HCPs about the effect of the nutrition interventions described in the INPs as a valuable part of their learning experience. They described a desire to be updated on the outcomes for the residents they had been involved with, being informed, for instance, about whether a resident had gained weight or not. One student said, "It was of great value to receive feedback on how the measures we suggested worked out ... . It is useful to know what may be practically challenging to implement."

The HCPs and nursing students possessed good patient knowledge and the students described depending on this information to understand the residents' individual situations. They emphasized the importance of co-operating with the HCPs to get an overview of the residents' daily routines, for instance in keeping track of the duration of a resident's overnight fast. The HCPs provided information about residents' mealtimes and sleeping patterns. The students suggested a late-evening meal for one patient to reduce restlessness at night. As one student said, "There were several factors the HCPs had experienced that could influence appetite, factors that I alone had not understood could differ from one day to the next. Without the HCPs' patient knowledge, it would have been much more challenging."

The students felt responsible for the residents in the nursing home through meeting and getting to know them, and they wanted to ensure that their individual needs were met. They described an increased interest in the aging population, which they perceived as a sometimes-neglected group in society. "I try to imagine myself in that situation," said one student, "and how I would like to be treated when you are not able to express what you want, when your memory is lost, or when you do not understand what is going on and you feel insecure."

The students described next of kin as important sources of information regarding the preferences of the residents, who were not always able to communicate them. The next of kin appreciated the students' competence and interest in their family member. The students emphasized the importance of knowing both the previous dietary habits of each resident and their preference for certain drinks or foods in order to provide 
8

Nutrition Students' Experiences of Interprofessional Learning

Heyerdahl, Ottesen, Molin, Hestevik, Sørlie, \& Sellevold

Journal of Research in Interprofessional Practice and Education

Vol. 10.1

2020 nutritional care according to their needs and likes. They experienced a conflict between nutrition theory and the joy of food and eating. They noted that they combined the two and reflected on what was most important in a specific setting. For example, they described serving a resident a Coke in the evening, as this was something she enjoyed; the woman was starting an overnight fast and had problems swallowing. One student noted, "I believe it is important to address these special treats they previously used to grant to themselves when no one else was responsible for their diet. It can easily be forgotten. A relative told us that her mother used to drink a glass of red wine with water and sugar in the evenings. It's important that this is also acknowledged."

\section{Discussion}

One theme was revealed through the structural analysis: A professional understanding of oneself and others. The study results showed that the nutrition students experienced being acknowledged as professionals who actively contributed to developing quality nutritional care. Through their interactions with HCPs, nursing students, and residents, the nutrition students experienced possessing a competence that was lacking in the practice setting, and they achieved an understanding of how they could contribute and collaborate to ensure resident care. The results demonstrated a high degree of involvement and engagement from the students. Actions and engagement are, according to Lillemyr [34], driven by motivation.

Seifert [35] argues that finding meaning is an important aspect of student motivation. The exposure to vulnerable residents in an authentic setting may have increased the nutrition students' feeling of performing meaningful work and fostered the courage and motivation to improve residents' nutritional status through developing quality nutritional care. The students' interactions with residents and their relatives touched them and contributed to their understanding of the residents as a vulnerable group. According to Henriksen [36], care involves assuming responsibility for those who are dependent. Being affected by the situation of others and being able to understand their needs is a prerequisite to acting responsibly [37]. This empathy may have given the students a sense of moral responsibility and driven them to care further for the residents. The students' stories about individualizing nutritional care touch upon aspects of person-centred care, which requires the carer to view the world through the patient's perspective in order to meet their individual needs [38]. The findings of this study are in line with a phenomenological-hermeneutical study of interprofessional practice among health professionals in which narratives had a patient-centred focus and revealed a spirit among the multidisciplinary team to act in the best interest of the patient [39].

The students did not emphasize theoretical knowledge and learning activities such as nutritional screening in their narratives. This may indicate that the students' most valuable learning occurred through action, reflection, and interactions with residents, next of kin, nursing students, and HCPs. The socio-cultural and social constructive learning theories emphasize the significance relations and interaction have for learning [40]. Learning happens in a social context where dialogue and interaction with others are important [41]. Molander [41] argues that knowledge in practice is developed and directed through our attentiveness, and it is enforced by 
9

Nutrition Students' Experiences of Interprofessional Learning

Heyerdahl, Ottesen, Molin, Hestevik, Sørlie, \& Sellevold

Journal of Research in Interprofessional Practice and Education

Vol. 10.1

2020 involvement and reflection in practical situations. In line with this, it is reasonable to believe that the nursing students, HCPs, residents, and next of kin constituted an important part of the socio-cultural learning environment for the nutrition students in this study.

The students emphasized the significance of exchanging knowledge and experience with HCPs, nursing students, and next of kin to develop quality care for the residents. They valued the competence of others and received positive feedback on their work, which made them feel valued. According to Ryan and Deci [42], feelings of competence and relatedness are keys to intrinsic motivation. Practice environments in which students feel valued and have a sense of belonging have been shown to be important for nutrition and dietetic students' confidence and self-efficacy [43]. Possessing unique expertise may have increased the students' feeling of competence in the present study. This is supported by Visser, Kusurkar, Croiset, Ten Cate, and Westerveld's [44] study on IPE and student motivation, which demonstrated that students with professional skills relatively unknown to the others in interprofessional teams gained increased autonomy and feeling of competency linked to their ability to add professional insight unfamiliar to others. The students in this study may have been motivated by the lack of nutritional competence in the nursing home and inspired by seeing the need for their expertise in a real-life setting. The students acquired a positive understanding of themselves and reported increased confidence. The increased confidence in their professional role is in line with other studies of nutrition and dietetic students participating in IPE [24,25].

Ryan and Deci [42] consider autonomy important for intrinsic motivation. In this study, the nutrition students experienced being active participants on the ward. Their apparent freedom of choice may have influenced their motivation and learning experience. Paris and Turner [45] introduced the concept of "situated motivation," in which student motivation depends on the context and learning environment. They emphasize that autonomy, choice, and control are central in student motivation and their degree of commitment. A recent study on IPE found that when students were given responsibility and the freedom to create collaborations, they profited from increased knowledge [46]. The nutrition students in this study had no mandatory activities to fulfil, other than the specific tasks they were instructed to complete as part of the interprofessional learning activities, nor were they expected to take part in the daily routine of their co-workers, yet they took initiative beyond what was expected in terms of the assignment and learning activities. A review of studies of other healthcare students showed that combining objectives for learning in a multidisciplinary team with profession-specific goals may be an obstacle to a positive IPE experience [47]. The nutrition students did not receive summative assessments by their supervisors, and their participation was voluntary. Studies have shown the positive impact of voluntary participation in IPE for student satisfaction [48]. Likewise, it has been shown that students feel free to act without fear of failure in a realistic environment in IPE in which they do not have to undergo a summative assessment [49].

In this study, students only spent four days on the ward. However, the importance of the preparation phase as well as the informal and formal meeting points, 
10

Nutrition Students' Experiences of Interprofessional Learning

Heyerdahl, Ottesen, Molin, Hestevik, Sørlie, \& Sellevold
Journal of Research in Interprofessional Practice and Education

Vol. 10.1

2020 where reflections were made with the nursing students, supervisors, and other HCPs, should not be underestimated. In a review of studies of the effects of IPE, several studies showed the importance of shared reflection and learning [48]. Studies have also shown the value of informal meeting places and informal communication in interprofessional collaboration [50].

\section{Methodological considerations}

Contrary to quantitative research, the aim of qualitative research is not to fulfil the traditional claims of validity, reliability, and generalizability [51]. The findings in this study cannot be generalized, but they may be transferable to similar situations or people [52].

According to Polkinghorne [53], narratives may provide a valuable source of knowledge about the human experience. Stories often touch us in a different way than factual information does, and an interpretation of these may give us a greater understanding of human experience. A focus-group interview may give us rich data through group dynamics, as informants are stimulated by and respond to each other's narratives [54].

Few informants in a qualitative study may ensure a high degree of content validity, meaning there is a high degree of detail in the data [51]. This approach permits a deeper insight into the phenomena under study and represents a strength of qualitative research. Three to five informants may be sufficient to achieve a high content validity, according to Mishler [32] and Brinkmann and Kvale [55]. Malterud, Siersma, and Guassora [56] have proposed the concept of "information power" concerning the number of informants in qualitative studies. They argue that when informants possess more information, fewer informants are needed, as the quality of the dialogue will influence the information power. In the present study, the quality of the dialogue was considered good; the informants were articulate and shared openly, resulting in rich descriptions. With only three participants, there was sufficient time for each individual to share their experiences. Likewise, throughout the interview, it ensured that all the participants were heard.

In line with the phenomenological-hermeneutic method, the authors interpreted data openly resulting in a comprehensive understanding of the lived experiences of the students. There are several ways of interpreting the text and this critical interpretation is only one way of understanding the text's meaning [30]. The authors of this study belong to three different academic institutions and have backgrounds in nutrition and nursing. Multiple researchers from different institutions and with different backgrounds may be considered a strength in the analytical process, as the researchers have supplemented each other with different pre-understandings and views.

\section{Conclusion}

This study showed that a short period of practical training in an authentic IPE setting with meaningful activities and a high degree of freedom seemed to increase the students' professional confidence and their motivation to act in the best interest of the residents. The nutrition students felt competent when meeting with residents and their next of kin, other students, and healthcare providers, and they felt they were doing meaningful work. They acquired a greater understanding of their own 
11

Nutrition Students' Experiences of Interprofessional Learning

Heyerdahl, Ottesen, Molin, Hestevik, Sørlie, \& Sellevold

Journal of Research in Interprofessional Practice and Education

Vol. 10.1

2020 role, as well as the roles of the others. The experience was clearly an eye-opener for the nutrition students, showing them how they can contribute to society.

\section{Abbreviations}

HCP: Healthcare provider

INP: Individual nutrition plan

IPE: Interprofessional education

\section{References}

1. European Federation of Associations of Dietitians. (2010). European practice placement standards for dietetics. URL: http://www.efad.org/media/1424/european-practice-placement-standards -for-dietetics.pdf [March 25, 2019].

2. Kunnskapsdepartementet. (2012, February 17). Meld. St. 13 (2011-2012): Utdanning for velferd. Regjeringen.no. Stortingsmelding. URL: https://www.regjeringen.no/no/dokumenter/meld-st -13-20112012/id672836/ [March 25, 2019].

3. Williams, B., Brown, T., \& Etherington, J. (2012). Learning styles of undergraduate nutrition and dietetics students. Journal of Allied Health, 41(4), 170-176.

4. Hammond, M.I., Myers, E.F., \& Trostler, N. (2014). Nutrition care process and model: An academic and practice odyssey. Journal of the Academy of Nutrition and Dietetics, 114(12), 1879-1894. doi: 10.1016/j.jand.2014.07.032

5. Hwalla, N., \& Koleilat, M. (2004). Dietetic practice: The past, present and future. Eastern Mediterranean Health Journal, 10(6), 716-730.

6. Cade, J.E., Eccles, E., Hartwell, H., Radford, S., Douglas, A., \& Milliner, L. (2012). The making of a nutrition professional: The Association for Nutrition register. Public Health Nutrition, 15(11), 2012-2019. doi: 10.1017/S1368980011003338

7. International Confederation of Dietetic Associations. (2016). International competency standards for dietitian-nutritionists. URL: http://www.efad.org/media/1424/european-practice-placement -standards-for-dietetics.pdf [March 30, 2019].

8. Association for Nutrition. (2019). Course certification (L1-5). URL: http://www.associationfor nutrition.org/default.aspx?tabid=213 [March 30, 2019].

9. Rogers, B., \& Schlossman, N. (1997). "Public Nutrition": The need for cross-disciplinary breadth in the education of applied nutrition professionals. Food and Nutrition Bulletin, 18(2), 120-133. doi: $10.1177 / 156482659701800211$

10. Eliot, K.A., \& Kolasa, K.M. (2015). The value in interprofessional, collaborative-ready nutrition and dietetics practitioners. Journal of the Academy of Nutrition and Dietetics, 115(10), 1578-1588. doi: $10.1016 /$ j.jand.2015.03.025

11. Helse-og omsorgsdepartementet. (2013, April 19). Meld. St. 29 (2012-2013): Morgendagens omsorg. Regjeringen.no. Stortingsmelding. URL: https:/www.regjeringen.no/no/dokumenter /meld-st-29-20122013/id723252/ [March 25, 2019].

12. World Health Organization. (2010). Framework for action on interprofessional education and collaborative practice. Geneva, CH: World Health Organization. URL: http://www.who.int/hrh /resources/framework_action/en/ [March 25, 2019].

13. Buring, S.M., Bhushan, A., Broeseker, A., Conway, S., Duncan-Hewitt, W., Hansen, L., \& Westberg, S. (2009). Interprofessional education: Definitions, student competencies, and guidelines for implementation. American Journal of Pharmaceutical Education, 73(4), 59.

14. Eliot, K.A., Wilson, M., Breitbach, A.P., \& Chushak-Polevska, M. (2017). Incorporation of Interprofessional Education in Nutrition and Dietetics Education Programs. Topics in Clinical Nutrition, 32(3), 184-192. doi: 10.1097/TIN.0000000000000106

15. Cereda, E., Pedrolli, C., Klersy, C., Bonardi, C., Quarleri, L., Cappello, S., Turri, A., Rondanelli, M., \& Caccialanza, R. (2016). Nutritional status in older persons according to healthcare setting: A systematic review and meta-analysis of prevalence data using MNA ${ }^{\circledR}$ Clinical Nutrition, 35(6), 1282-1290. doi: 10.1016/j.clnu.2016.03.008

16. Landmark, B.T., Gran, S.V., \& Grov, E.K. (2014). Ernæringsstatus blant pasienter i sykehjem og i hjemmesykepleien kartlagt ved hjelp av Ernæringsjournalen. Klinisk Sygepleje, 28(01), 4-14. URL: https://www.idunn.no/klinisk_sygepleje/2014/01/ernaeringsstatus_blant_pasienter_i_ sykehjem_og_i_hjemmesykep [March 30, 2019]. 
Nutrition Students' Experiences of Interprofessional Learning

Heyerdahl, Ottesen, Molin, Hestevik, Sørlie, \& Sellevold

Journal of Research in Interprofessional Practice and Education

Vol. 10.1

2020
17. Helse-og omsorgsdepartementet. (2018, May 4). Meld. St. 15 (2017-2018): Leve hele livet - En kvalitetsreform for eldre. Regjeringen.no. Stortingsmelding. URL: https://www.regjeringen.no /no/dokumenter/meld.-st.-15-20172018/id2599850/ [March 25, 2019].

18. Volkert, D., Beck, A.M., Cederholm, T., Cruz-Jentoft, A., Goisser, S., Hooper, L., Kiesswetter, E., Maggio, M., Raynaud-Simon, A., Sieber, C., Sobotka, L, van Asselt, D., Wirth, R., \& Bischoff, S.C. (2019). ESPEN guideline on clinical nutrition and hydration in geriatrics. Clinical Nutrition, 38(1), 10-47. doi: 10.1016/j.clnu.2018.05.024

19. World Health Organization. (2017). WHO guidelines on integrated care for older people (ICOPE). Geneva, CH: World Health Organization. URL: http://www.who.int/ageing/publications /guidelines-icope/en/ [March 25, 2019].

20. Departementene. (2017, March 7). Nasjonal handlingsplan for bedre kosthold (2017-2021) Sunt kosthold, måltidsglede og god helse for alle! Regjeringen.no. Plan. URL: https://www.regjeringen.no/no /dokumenter/nasjonal-handlingsplan-for-bedre-kosthold-20172021/id2541870/ [March 25, 2019].

21. Brehm, B., Breen, P., Brown, B., Long, L., Smith, R., Wall, A., \& Warren, N.S. (2006). An interdisciplinary approach to introducing professionalism. American Journal of Pharmaceutical Education, 70(4), 81.

22. Earland, J., Gilchrist, M., McFarland, L., \& Harrison, K. (2011). Dietetics students' perceptions and experiences of interprofessional education. Journal of Human Nutrition and Dietetics: The Official Journal of the British Dietetic Association, 24(2), 135-143. doi: 10.1111/j.1365-277X .2010.01141.x

23. Soubra, L., Badr, S.B.Y., Zahran, E.M., \& Aboul-Seoud, M. (2018). Effect of interprofessional education on role clarification and patient care planning by health professions students. Health Professions Education, 4(4), 317-328. doi: 10.1016/j.hpe.2017.12.005

24. Costello, M., Prelack, K., Faller, J., Huddleston, J., Adly, S., \& Doolin, J. (2018). Student experiences of interprofessional simulation: Findings from a qualitative study. Journal of Interprofessional Care, 32(1), 95-97. doi: 10.1080/13561820.2017.1356810

25. Darlow, B., Coleman, K., McKinlay, E., Donovan, S., Beckingsale, L., Gray, B., Neser, H., Perry, M., Stanley, J., \& Pullon, S. (2015). The positive impact of interprofessional education: A controlled trial to evaluate a programme for health professional students. BMC Medical Education, 15, 98. doi: 10.1186/s12909-015-0385-3

26. van Schaik, S.M., Regehr, G., Eva, K.W., Irby, D.M., \& O’Sullivan, P.S. (2016). Perceptions of peerto-peer interprofessional feedback among students in the health professions. Academic Medicine: Journal of the Association of American Medical Colleges, 91(6), 807-812. doi: 10.1097 /ACM.0000000000000981

27. Whelan, K., Thomas, J.E., Cooper, S., Hilton, R., Jones, S.C., Newton, T., O’Neill, B., \& Gill, E.E. (2005). Interprofessional education in undergraduate healthcare programmes: The reaction of student dietitians. Journal of Human Nutrition and Dietetics: The Official Journal of the British Dietetic Association, 18(6), 461-466. doi: 10.1111/j.1365-277X.2005.00650.x

28. Wilby, K.J., Al-Abdi, T., Hassan, A., Brown, M.A., Paravattil, B., \& Khalifa, S.I. (2015). Attitudes of pharmacy and nutrition students towards team-based care after first exposure to interprofessional education in Qatar. Journal of Interprofessional Care, 29(1), 82-84. doi: 10.3109 /13561820.2014.933949

29. Williams, B., McCook, F., Brown, T., Palmero, C., McKenna, L., Boyle, M., Scholes, R., French, J., \& McCall, L. (2012). Are undergraduate health care students 'ready' for interprofessional learning? A cross-sectional attitudinal study. Internet Journal of Allied Health Sciences and Practice, 10 (3). URL: https://nsuworks.nova.edu/ijahsp/vol10/iss3/4 [March 30, 2019].

30. Ricœur, P. (1976). Interpretation theory: Discourse and the surplus of meaning. Fort Worth, TX: Texas Christian University Press.

31. Malterud, K. (2012). Fokusgrupper som forskningsmetode for medisin og helsefag. Oslo, NO: Universitetsforlaget.

32. Mishler, E.G. (1986). Research interviewing: Context and narrative. Cambridge, MA: Harvard University Press.

33. Lindseth, A., \& Norberg, A. (2004). A phenomenological hermeneutical method for researching lived experience. Scandinavian Journal of Caring Sciences, 18(2), 145-153. doi: 10.1111/j.1471 $-6712.2004 .00258 . \mathrm{x}$

34. Lillemyr. (2007). Motivasjon og selvforståelse. Oslo, NO: Universitetsforlaget.

35. Seifert, T. (2004). Understanding student motivation. Educational Research, 46(2), 137-149. doi: $10.1080 / 0013188042000222421$ 
13

Nutrition Students' Experiences of Interprofessional Learning

Heyerdahl, Ottesen, Molin, Hestevik, Sørlie, \& Sellevold
36. Henriksen, J.-O. (2006). Norhet og distanse: grunnlag, verdier og etiske teorier $i$ arbeid med mennesker (3. utg.). Oslo, NO: Gyldendal akademisk.

37. Lindseth, A. (2002). Løgstrups etikk $i$ et omsorgsperspektiv. Forlaget ANIS.

38. McCormack, B., McCance, T., \& Klopper, H. (2017). Person-centred practice in nursing and health care: Theory and practice (2nd ed.). West Sussex, UK: Wiley Blackwell.

39. Flood, B., Hocking, C., Smythe, L., \& Jones, M. (2019). Working in a spirit of interprofessional practice: A hermeneutic phenomenological study. Journal of Interprofessional Care, 33(6), 744-752. doi: 10.1080/13561820.2019.1577810

40. Sylte, A.L. (2016). Profesjonspedagogikk: Profesjonsretting/yrkesretting av pedagogikk og didaktikk (2. utg.). Oslo, NO: Gyldendal akademisk.

41. Molander, B. (2015). The practice of knowing and knowing in practices. Frankfurt, DE: Peter Lang.

42. Ryan, R.M., \& Deci, E.L. (2000). Self-determination theory and the facilitation of intrinsic motivation, social development, and well-being. American Psychologist, 55(1), 68-78. doi: 10.1037 /0003-066X.55.1.68

43. Maher, J., Pelly, F., Swanepoel, E., Sutakowsky, L., \& Hughes, R. (2015). The contribution of clinical placement to nutrition and dietetics competency development: A student-centred approach. Nutrition \& Dietetics, 72(2), 156-162. doi: 10.1111/1747-0080.12163

44. Visser, C.L.F., Kusurkar, R.A., Croiset, G., Ten Cate, O., \& Westerveld, H.E. (2019). Students' motivation for interprofessional collaboration after their experience on an IPE ward: A qualitative analysis framed by self-determination theory. Medical Teacher, 41(1), 44-52. doi: 10.1080/0142 159X.2018.1436759

45. Paris, S.G., \& Turner, J.C. (1994). Situated motivation. In P. Pintrich, D. Brown, \& C.E. Weinstein (Eds.), Student motivation, cognition, and learning: Essays in honor of Wilbert J. McKeachie (pp. 213-237). Hillsdale, NJ: Lawrence Erlbaum Associates, Inc.

46. Gudmundsen, A.C., Norbye, B., Dahlgren, M.A., \& Obstfelder, A. (2018). Interprofessional education: Students' learning of joint patient care. Professions and Professionalism, 9(1). doi: 10.7577 /pp.3126

47. Visser, C.L.F., Ket, J.C.F., Croiset, G., \& Kusurkar, R.A. (2017). Perceptions of residents, medical and nursing students about Interprofessional education: A systematic review of the quantitative and qualitative literature. BMC Medical Education, 17(1), 77. doi: 10.1186/s12909-017-0909-0

48. Reeves, S., Fletcher, S., Barr, H., Birch, I., Boet, S., Davies, N., McFadyen, A., Rivera, J., \& Kitto, S. (2016). A BEME systematic review of the effects of interprofessional education: BEME Guide No. 39. Medical Teacher, 38(7), 656-668. doi: 10.3109/0142159X.2016.1173663

49. Mellor, R., Cottrell, N., \& Moran, M. (2013). "Just working in a team was a great experience...": Student perspectives on the learning experiences of an interprofessional education program. Journal of Interprofessional Care, 27(4), 292-297. doi: 10.3109/13561820.2013.769093

50. Morgan, S., Pullon, S., \& McKinlay, E. (2015). Observation of interprofessional collaborative practice in primary care teams: An integrative literature review. International Journal of Nursing Studies, 52(7), 1217-1230. doi: 10.1016/j.ijnurstu.2015.03.008

51. Dehlholm-Lambertsen, B., \& Maunsbach, M. (1997). Vitenskapsteori og anvendelse. Nordisk Medicin, 112(1), 24-27.

52. Malterud, K. (2001). Qualitative research: Standards, challenges, and guidelines. Lancet, 358(9280), 483-488. doi: 10.1016/S0140-6736(01)05627-6

53. Polkinghorne, D.E. (1988). Narrative knowing and the human sciences. Albany, NY: State University of New York Press.

54. Polit, D.F., \& Beck, C.T. (2012). Nursing research: Generating and assessing evidence for nursing practice (9th ed.). Philadelphia, PA: Wolters Kluwer Health.

55. Svend Brinkmann, \& Kvale, S. (2015). InterViews: Learning the craft of qualitative research interviewing (3rd ed.). Thousand Oaks, CA: Sage.

56. Malterud, K., Siersma, V.D., \& Guassora, A.D. (2016). Sample size in qualitative interview studies: Guided by information power. Qualitative Health Research, 26(13), 1753-1760. doi: 10.1177 /1049732315617444
Journal of Research in Interprofessional Practice and Education

Vol. 10.1

2020 